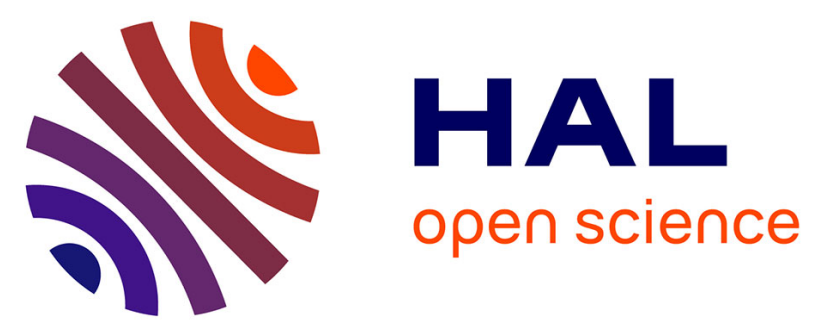

\title{
New bidimensional honeycomb CoII-FeIII and brick wall FeII-CoIII cyanido-bridged coordination polymers: Synthesis, crystal structures and magnetic properties
} Andreea Dogaru, Céline Pichon, Rodica Ababei, Dmitri Mitcov, Catalin Maxim, Loïc Toupet, Corine Mathonière, Rodolphe Clérac, Marius Andruh

\section{To cite this version:}

Andreea Dogaru, Céline Pichon, Rodica Ababei, Dmitri Mitcov, Catalin Maxim, et al.. New bidimensional honeycomb CoII-FeIII and brick wall FeII-CoIII cyanido-bridged coordination polymers: Synthesis, crystal structures and magnetic properties. Polyhedron, 2014, 75, pp.146-152. 10.1016/j.poly.2014.03.025 . hal-00988867

\section{HAL Id: hal-00988867 https://hal.science/hal-00988867}

Submitted on 8 Jul 2014

HAL is a multi-disciplinary open access archive for the deposit and dissemination of scientific research documents, whether they are published or not. The documents may come from teaching and research institutions in France or abroad, or from public or private research centers.
L'archive ouverte pluridisciplinaire HAL, est destinée au dépôt et à la diffusion de documents scientifiques de niveau recherche, publiés ou non, émanant des établissements d'enseignement et de recherche français ou étrangers, des laboratoires publics ou privés. 


\title{
New bidimensional honeycomb $\mathrm{Co}^{\mathrm{II}}-\mathrm{Fe}^{\mathrm{III}}$ and brick wall $\mathrm{Fe}^{\mathrm{II}}-\mathrm{Co}^{\mathrm{III}}$ cyanido- bridged coordination polymers: Synthesis, crystal structures and magnetic properties
}

\author{
Andreea Dogaru, ${ }^{a}$ Céline Pichon, ${ }^{b, c}$ Rodica Ababei, ${ }^{b, c, d, e}$ Dmitri Mitcov, ${ }^{b, c}$ Catalin Maxim, ${ }^{a}$ \\ Loïc Toupet, ${ }^{f}$ Corine Mathonière, ${ }^{d, e}$ Rodolphe Clérac, ${ }^{* b, c}$ Marius Andruh*a \\ ${ }^{a}$ Inorganic Chemistry Laboratory, Faculty of Chemistry, University of Bucharest, Str. Dumbrava \\ Rosie nr. 23, 020464, Bucharest, Romania.E-mail: mandruh@yahoo.com \\ ${ }^{b}$ CNRS, CRPP, UPR 8641, F-33600 Pessac, France.; E-mail: clerac@crpp-bordeaux.cnrs.fr \\ ${ }^{c}$ Univ. Bordeaux, CRPP, UPR 8641, F-33600 Pessac, France \\ ${ }^{d}$ CNRS, ICMCB, UPR 9048, F-33600 Pessac, France \\ ${ }^{e}$ Univ. Bordeaux, ICMCB, UPR 9048, F-33600 Pessac, France \\ ${ }^{f}$ Institut de Physique de Rennes, UMR 6251, Université de Rennes 1-CNRS, Rennes, France
}

Keywords: Heterometallic complexes; Cyanido-bridged complexes; Iron complexes; Cobalt complexes; Magnetic properties.

New bidimensional cyanido-bridged heterometallic coordination polymers, $\left[\left\{\mathrm{Co}\left(\mathrm{L}^{1}\right)\right\}_{3}\left\{\mathrm{Fe}(\mathrm{CN})_{6}\right\}_{2}\right] \cdot 6 \mathrm{CH}_{3} \mathrm{OH} \cdot 6 \mathrm{H}_{2} \mathrm{O}$ (1) and $\left[\left\{\mathrm{Fe}\left(\mathrm{L}^{2}\right)\right\}_{3}\left\{\mathrm{Co}(\mathrm{CN})_{6}\right\}_{2}\right] \cdot 2 \mathrm{CH}_{3} \mathrm{OH} \cdot 13 \mathrm{H}_{2} \mathrm{O}$ (2), have been assembled following a building-block approach $\left(\mathrm{L}^{1}\right.$ and $\mathrm{L}^{2}$ are macrocyclic ligands obtained by the template condensation between 2,6-diacetylpyridine and 3,4-dioxaoctane-1,8diamine, and triethylenetetramine, respectively). The crystal structure of $\mathbf{1}$ consists of honeycomb layers, each $\left[\mathrm{Fe}^{\mathrm{III}}(\mathrm{CN})_{6}\right]^{3-}$ unit connecting three $\left[\mathrm{Co}\left(\mathrm{L}^{1}\right)\right]^{2+}$ nodes through three facial cyanido groups. On the other hand, the self-assembly process between $\left[\mathrm{Co}^{\mathrm{III}}(\mathrm{CN})_{6}\right]^{3-}$ and $\left[\mathrm{Fe}\left(\mathrm{L}^{2}\right)\right]^{2+}$ ions affords 2-D layers with a brick wall topology. Each $\left[\mathrm{Co}{ }^{\mathrm{III}}(\mathrm{CN})_{6}\right]^{3-}$ metalloligand is surrounded by three $\left[\mathrm{Fe}\left(\mathrm{L}^{2}\right)\right]^{2+}$ units, which adopt a meridional configuration around the cobalt metalloligand for compound 2. The magnetic properties of the two compounds have been 
investigated. Compound 1 shows a ferromagnetic order below $3 \mathrm{~K}$. The magnetic properties of 2 are characteristic of non-interacting high spin $\mathrm{Fe}^{\mathrm{II}}$ ions, which exhibit a moderate uniaxial magnetic anisotropy $\left(D / k_{\mathrm{B}}=-5.5 \mathrm{~K}\right)$.

\section{Introduction}

The high interest in the chemistry of heterometallic cyanido-bridged complexes was triggered by the synthesis of the first molecular magnets with high critical temperatures, which belong to the Prussian Blues family [1]. Another milestone in this field is due to Ohba, Okawa et al. [2], who showed that the hexacyanido-complexes can be used as metalloligands not only towards bare (actually hydrated) metal ions, but also towards complex cations with one or more coordination sites blocked by ancillary ligands. Following this strategy, a plethora of cyanido-bridged complexes with interesting magnetic properties have been described [3]. The denticity of the ancillary ligands has a strong influence on the nature of the polymetallic cyanido-bridged complexes resulted from the self-assembly processes (oligonuclear species versus coordination polymers with various dimensionalities and network topologies). A rich variety of organic molecules can be used to block several coordination sites of the assembling cations with various denticities (ranging from monodentate to pentadentate), geometries (e.g. linear, tripodal or macrocyclic) and charge (neutral or often anionic). Let us recall briefly the case of macrocyclic blocking ligands. They are usually coordinated into the equatorial plane of the metal ions, the axial positions being occupied by weakly bonded groups (usually solvent molecules), which can be easily replaced by cyanido bridges. Generally, the self-assembly process involving trans$\left[\mathrm{M}(\mathrm{mac})(\mathrm{solv})_{2}\right]^{2+}$ (where mac stands for macrocyclic ligand) and $\left[\mathrm{M}^{\prime}(\mathrm{CN})_{6}\right]^{3-}$ ions yields 2-D $\left[\mathrm{M}_{3} \mathrm{M}_{2}^{\prime}\right]$ networks. Within a layer, each $[\mathrm{M}(\mathrm{mac})]^{2+}$ moiety is linked to two $\left[\mathrm{M}^{\prime}(\mathrm{CN})_{6}\right]^{3-}$ ions in trans positions, and each $\left[\mathrm{M}^{\prime}(\mathrm{CN})_{6}\right]^{3-}$ ion is surrounded by three $[\mathrm{M}(m a c)]^{2+}$ units. If the $\left[\mathrm{M}(\mathrm{CN})_{6}\right]^{3-}$ tecton employs three facial cyanido groups as bridges, layers with a stair-shaped honeycomb architecture are formed [4]. On the other hand, flat brick wall-like layers are assembled when the three cyanido bridges are disposed in meridional positions [5].

Two interesting macrocyclic ligands, $\mathrm{L}^{1}$ and $\mathrm{L}^{2}$, both potentially pentadentate, result from the condensation reaction of 2,6-diacetylpyridine with 3,4-dioxaoctane-1,8-diamine, and 
triethylenetetramine, respectively (Scheme 1). These two ligands favour a pentagonal bipyramidal geometry around metal ions. Another important property of these ligands arised from the coordination geometry imposed to the metal ions. They generate very robust $\mathrm{Co}^{\mathrm{II}}$ and $\mathrm{Mn}^{\mathrm{II}}$ complexes with high preference for octahedral coordination and prevent their oxidation to $\mathrm{Co}^{\mathrm{III}}$ and $\mathrm{Mn}^{\mathrm{III}}$, respectively. Moreover, it has been shown that the geometry of these ligands can enhance the local magnetic anisotropy of high spin $\mathrm{Fe}^{\mathrm{II}}$ complexes [6]. Interestingly, the selfassembly process between $\left[\mathrm{M}\left(\mathrm{L}^{1 / 2}\right)(\text { solv })_{2}\right]^{2+}$ and $\left[\mathrm{M}^{\prime}(\mathrm{CN})_{6}\right]^{3-}$ ions do not always lead to 2-D coordination polymers. For example, by reacting $\left[\mathrm{Mn}\left(\mathrm{L}^{2}\right)\left(\mathrm{H}_{2} \mathrm{O}\right)_{2}\right] \mathrm{Cl}_{2}$ with $\mathrm{K}_{3}\left[\mathrm{Fe}(\mathrm{CN})_{6}\right]$, we obtained a linear pentanuclear $\left[\mathrm{Mn}_{3}^{\mathrm{II}} \mathrm{Fe}^{\mathrm{III}}{ }_{2}\right]$ complex [7], while reactions between $\left[\mathrm{Mn}\left(\mathrm{L}^{2}\right)\left(\mathrm{H}_{2} \mathrm{O}\right)_{2}\right] \mathrm{Cl}_{2}$ and $\mathrm{K}_{3}\left[\mathrm{Cr}(\mathrm{CN})_{6}\right]$ afforded the trinuclear species, $\left[\left(\mathrm{H}_{2} \mathrm{O}\right)\left(\mathrm{L}^{2}\right) \mathrm{MnCr}(\mathrm{CN})_{6} \mathrm{Mn}\left(\mathrm{L}^{2}\right)\left(\mathrm{H}_{2} \mathrm{O}\right)\right]^{+} \quad[8]$. The self-assembly between $\left[\mathrm{Mn}\left(\mathrm{L}^{1}\right)\right]^{2+}$ with $\left[\mathrm{M}^{\prime}(\mathrm{CN})_{6}\right]^{3-}$, where $\mathrm{M}=\mathrm{Cr}^{\mathrm{III}}, \mathrm{Fe}^{\mathrm{III}}$, led to three types of compounds: a trinuclear species, several 1-D and one 2-D coordination polymers [9]. The 2-D coordination polymer, $\left[\left\{\mathrm{Mn}\left(\mathrm{L}^{1}\right)\right\}_{3}\left\{\mathrm{Fe}(\mathrm{CN})_{6}\right\}_{2}\right]$, does not show any of the expected topologies, i.e. honeycomb or brick wall. It is indeed a wavy grid-like layer with rectangular meshes, constructed from two types of $\left\{\mathrm{Fe}(\mathrm{CN})_{6}\right\}$ linkers: one type employs three meridional cyanido groups for the interaction with the manganese ions, while the other one involves two trans cyanido groups. It is actually the only example of a bidimensional coordination polymer constructed from hexacyanido metalloligands and heptacoordinated assembling cations carrying the pentadentate macrocyclic ligands, $\mathrm{L}^{1}$ or $\mathrm{L}^{2}$ [9]. Finally, the 3-D coordination polymer, $\left[\left\{\mathrm{Co}\left(\mathrm{L}^{1}\right)\right\}\left\{\mathrm{Cr}(\mathrm{CN})_{6}\right\}\right] \mathrm{ClO}_{4} \cdot 8 \mathrm{H}_{2} \mathrm{O}$, resulted from the association of $\left[\mathrm{Co}\left(\mathrm{L}^{1}\right)\right]^{2+}$ with $\left[\mathrm{Cr}(\mathrm{CN})_{6}\right]^{3-}$, has been reported by Sato et al [10]. Herein, we report the first examples of 2-D coordination networks with honeycomb and brick wall topologies, which are constructed using $\left[\mathrm{M}\left(\mathrm{L}^{1 / 2}\right)\right]^{2+}$ assembling cations $(\mathrm{M}=\mathrm{Co}, \mathrm{Fe})$ and $\left[\mathrm{M}^{\prime}(\mathrm{CN})_{6}\right]^{3-}$ metalloligands $\left(\mathrm{M}^{\prime}=\mathrm{Fe}^{\mathrm{III}}, \mathrm{Co}^{\mathrm{III}}\right)$. Their synthesis, crystal structure and magnetic properties were investigated and analyzed.

\section{Experimental}

\subsection{Materials and methods}

Commercially available reagents were used without further purification. The two precursors, $\left[\mathrm{Co}\left(\mathrm{L}^{1}\right)\left(\mathrm{H}_{2} \mathrm{O}\right)_{2}\right] \mathrm{Cl}_{2}$ and $\left[\mathrm{Fe}\left(\mathrm{L}^{2}\right)\left(\mathrm{H}_{2} \mathrm{O}\right)_{2}\right] \mathrm{Cl}_{2}$, were obtained following the synthetic procedures reported in the literature [6], [10]. The synthesis of 2 was performed in a glove box operating 
under argon using degassed solvent by freeze-pump-thaw technique prior to use.

\subsection{Physical measurements}

The IR spectra were collected in the $4000-400 \mathrm{~cm}^{-1}$ range on a Bruker Tensor 37 spectrometer for 1 ( $\mathrm{KBr}$ pellets) and on a Thermal Scientific Nicolet 6700 spectrometer equipped with a Smart iTR diamond window for 2. Magnetic measurements were carried out with a Quantum Design MPMS-XL SQUID magnetometer equipped with a $7 \mathrm{~T}$ magnet. Measurements were performed on crystals of $\mathbf{1}(7.9 \mathrm{mg})$ and $\mathbf{2}(13.6 \mathrm{mg})$ covered and thus restrained in a minimum of their frozen mother liquor within a sealed straw to prevent desolvation of the solid. No evaporation of the mother liquor was observed during the measurements. The mass of the sample was determined after the measurements and subsequent mother liquor evaporation. These measurements were collected in the temperature range $1.8-280 \mathrm{~K}$ and in the field range -7 to $7 \mathrm{~T}$. An $M$ vs. $H$ measurement was performed at $100 \mathrm{~K}$ to confirm the absence of ferromagnetic impurities. Ac magnetic susceptibility data were collected in zero dc field in the temperature range 1.8-10 K, under an ac field of $3 \mathrm{Oe}$, oscillating at frequencies in the range 1-1000 Hz. The magnetic susceptibility data were corrected for the sample holder and the diamagnetic contributions.

\subsection{Synthesis}

\subsubsection{Synthesis of complex 1}

$\left[\left\{\mathbf{C o}\left(\mathbf{L}^{\mathbf{1}}\right)\right\}_{3}\left\{\mathbf{F e}(\mathbf{C N})_{6}\right\}_{2}\right] \cdot \mathbf{6 C H}_{3} \mathbf{O H} \cdot \mathbf{6 H}_{\mathbf{2}} \mathrm{O}(\mathbf{1}) . \mathrm{K}_{3}\left[\mathrm{Fe}(\mathrm{CN})_{6}\right](23 \mathrm{mg}, 0.07 \mathrm{mmol})$ in $\mathrm{H}_{2} \mathrm{O}(3 \mathrm{~mL})$ was introduced in a $1.5 \mathrm{~cm}$ diameter tube and layered with $10 \mathrm{~mL} \mathrm{CH}_{3} \mathrm{OH} / \mathrm{CH}_{3} \mathrm{CN} \mathrm{1:1.} \mathrm{A} \mathrm{methanolic}$ solution (3mL) containing $\left[\mathrm{Co}\left(\mathrm{L}^{1}\right)\left(\mathrm{H}_{2} \mathrm{O}\right)_{2}\right] \mathrm{Cl}_{2}(46 \mathrm{mg}, 0.1 \mathrm{mmol})$ was then layered. After 2-3 days, green crystals were formed at the interface, collected and dried with diethylether. Yield 20 mg (42\%, based on Co for $\left.\mathrm{C}_{57} \mathrm{H}_{75} \mathrm{Co}_{3} \mathrm{Fe}_{2} \mathrm{~N}_{21} \mathrm{O}_{12}\right)$. IR data $\left(\mathrm{cm}^{-1}\right)$ : IR data $\left(\bar{v} / \mathrm{cm}^{-1}\right)$ : 3349 (w, NH), 2927 (w), 2881 (w), 2124, 2110 (m, conj. CN), 1647 (m), 1588 (m), 1423 (m), 1369 (m), 1354 (m), 1270 (w), 1242 (m), 1203 (m), 1123 (w), 1097 (w), 1080 (m), 1045 (m), 957 (w), 896 (w), 836(w), $816(\mathrm{~s}), 743(\mathrm{~m}), 728(\mathrm{~m}), 652(\mathrm{~m}), 583(\mathrm{w}), 617(\mathrm{w}), 572(\mathrm{w})$.

\subsubsection{Synthesis of complex 2}

$\left[\left\{\mathbf{F e}\left(\mathbf{L}^{2}\right)\right\}_{3}\left\{\mathrm{Co}(\mathbf{C N})_{6}\right\}_{2}\right] \cdot \mathbf{2} \mathbf{C H}_{3} \mathbf{O H} \cdot \mathbf{1 3 H}_{2} \mathbf{O}(\mathbf{2}) . \mathrm{K}_{3}\left[\mathrm{Co}(\mathrm{CN})_{6}\right](16 \mathrm{mg}, 0.05 \mathrm{mmol})$ in $\mathrm{H}_{2} \mathrm{O}(2 \mathrm{~mL})$ 
was introduced in a $1.5 \mathrm{~cm}$ diameter tube and layered with $1 \mathrm{~mL} \mathrm{CH}_{3} \mathrm{OH} / \mathrm{H}_{2} \mathrm{O}$ 1:1. A solution of $\left[\mathrm{Fe}\left(\mathrm{L}^{2}\right)\left(\mathrm{H}_{2} \mathrm{O}\right)_{2}\right] \mathrm{Cl}_{2}(26 \mathrm{mg}, 0.05 \mathrm{mmol})$ dissolved in $\mathrm{CH}_{3} \mathrm{OH}(2 \mathrm{~mL})$ was layered very carefully. After 1 day, big dark blue crystals appeared at the interface, which were collected and dried with diethylether. Yield: $15 \mathrm{mg}$ (55\% based on $\mathrm{Fe}$ for $\mathrm{C}_{59} \mathrm{H}_{95} \mathrm{Co}_{2} \mathrm{Fe}_{3} \mathrm{~N}_{27} \mathrm{O}_{13}$ ). Anal. calcd for $\mathrm{C}_{57} \mathrm{H}_{95} \mathrm{Co}_{2} \mathrm{Fe}_{3} \mathrm{~N}_{27} \mathrm{O}_{13}(2-2 \mathrm{MeOH}, 1651.95 \mathrm{~g} / \mathrm{mol})$ : C 41.44; H 5.80; N 22.89\%. Found C 41.6; H $5.0 ; \mathrm{N} 23.1 \%$. The crystals are quickly losing some solvent molecules as seen by the fast loss of crystallinity during the crystal mounting. Methanol molecules are expected to leave easily compared to water ones so the elemental analysis was calculated for $\left[\left\{\mathrm{Fe}\left(\mathrm{L}^{2}\right)\right\}_{3}\left\{\mathrm{Co}(\mathrm{CN})_{6}\right\}_{2}\right] \cdot 13 \mathrm{H}_{2} \mathrm{O}$. IR data $\left(\bar{v} / \mathrm{cm}^{-1}\right): 3283(\mathrm{w}, \mathrm{NH}), 2920(\mathrm{w}), 2862(\mathrm{w}), 2122(\mathrm{~s}$, conj. CN), 1639 (s), 1589 (m), 1461 (w), 1426 (m), 1378 (m), 1351 (m), 1289 (w), 1267 (m), 1198 (m), 1180 (w), 1125 (w), 1109 (m), 1049 (m), 961 (w), 914 (w), 887 (w), 813 (s), 742 (m), $728(\mathrm{~m}), 651(\mathrm{~m}), 624(\mathrm{w}), 617(\mathrm{w}), 608(\mathrm{w})$.

\subsection{X-ray data collection and crystal structure refinement}

The crystals are losing quickly their interstitial solvent molecules once filtered from their mother solution, resulting in a loss of crystallinity. For this reason, the crystals were mounted on a fiber loop and immediately placed under the nitrogen flux to prevent desolvatation. X-ray diffraction measurements for crystal 1 were performed at $173 \mathrm{~K}$ on a STOE IPDS II diffractometer operating with $\operatorname{Mo}_{K \alpha}(\lambda=0.71073 \AA) \mathrm{X}$-ray tube with graphite monochromator. A four-circle Oxford Diffraction Xcalibur 3 diffractometer with graphite-monochromated Mo- Ka radiation ( $\lambda$ $=0.71073 \AA$ A) with a 2D Saphire 3 CCD detector coupled with an Oxford CryoSystem nitrogenflow cryostat was used for the data collection at 100(2) K of 2. The structures were solved by direct methods and refined by full-matrix least squares techniques based on $F^{2}$. The unit cell parameters and the data integration of $\mathbf{2}$ were respectively obtained with the CrysAlis CCD and CrysAlis RED programs from Oxford Diffraction [11]. The structure of 1 was solved with the SHELX-97 crystallographic software package [12], while 2 was solved using SIR-97 [13], and refined by a full-matrix least squares method on $F^{2}$ with SHELXL-97. The non-H atoms were refined with anisotropic displacement parameters. Hydrogen atoms were located at calculated positions using suitable riding models except the ones on methanol and water molecules that were not introduced, but are taken into account in the compound formula. The structure of 2 presents a disorder rather difficult on one of the two macrocyclic complex contained in the unit 
cell. Also, it was necessary to use numerous restraints and set isotropic four nitrogen atoms. C29 and N14 from a cyanide group coordinated to $\mathrm{Co}(1)$ are disordered on two positions and were refined with relative occupations of $0.642: 0.358$. A summary of the crystallographic data and the structure refinement for crystals $\mathbf{1}$ - $\mathbf{2}$ are given in Table 2.

\section{Results and Discussion}

\subsection{Syntheses and general description}

The two compounds, $\quad\left[\left\{\mathrm{Co}\left(\mathrm{L}^{1}\right)\right\}_{3}\left\{\mathrm{Fe}(\mathrm{CN})_{6}\right\}_{2}\right] \cdot 6 \mathrm{CH}_{3} \mathrm{OH} \cdot 6 \mathrm{H}_{2} \mathrm{O} \quad$ (1) and $\left[\left\{\mathrm{Fe}\left(\mathrm{L}^{2}\right)\right\}_{3}\left\{\mathrm{Co}(\mathrm{CN})_{6}\right\}_{2}\right] \cdot 2 \mathrm{CH}_{3} \mathrm{OH} \cdot 13 \mathrm{H}_{2} \mathrm{O}(2)$, have been obtained in a similar way, by slow diffusion of a solution containing the assembling cation, $\left[\mathrm{M}\left(\mathrm{L}^{1 / 2}\right)\right]^{2+}$, into the solution of the corresponding hexacyanometallate. The characteristic bands of the cyanido group are observed by infrared spectroscopy for the two compounds as follows: 2145 and $2110 \mathrm{~cm}^{-1}$ for $\mathbf{1}$, and 2122 $\mathrm{cm}^{-1}$ for 2 .

\subsection{Crystal structure of complex 1}

The crystallographic investigation of the two compounds reveals an assembly of layers with different topologies driven by the relative position of the three bridging groups from the hexacyanidometallo-ligands (facial for $\left\{\mathrm{Fe}(\mathrm{CN})_{6}\right\}$ in 1 and meridional for $\left\{\mathrm{Co}(\mathrm{CN})_{6}\right\}$ in 2). The asymmetric unit for 1, presented in Figure 1, reveals two crystallographically independent heptacoordinated cobalt ions, both with a pentagonal bipyramidal stereochemistry. Their equatorial plane is occupied by the macrocyclic $\mathrm{L}^{1}$ ligand, with metal-donor atom distances varying between 2.318(3) and 2.117(3) $\AA$ for Co1 and between 2.257(2) and 2.127(4) $\AA$ for Co2. The Co - O bond lengths are slightly longer than the Co - N ones (Co1 - O1 = 2.318(3), Co1 $\mathrm{N} 2=2.186(3), \mathrm{Co} 1-\mathrm{N} 9=2.117(3), \mathrm{Co} 1-\mathrm{N} 1=2.182(3), \mathrm{Co} 1-\mathrm{O} 2=2.275(3), \mathrm{Co} 2-\mathrm{O} 3=$ 2.257(2) $\mathrm{A}, \mathrm{Co} 2-\mathrm{N} 11=2.195(3), \mathrm{Co} 2-\mathrm{N} 10=2.127(4) \AA)$. The apical positions are occupied by the nitrogen atoms arising from the cyanido bridges $\left(\mathrm{Co} 1-\mathrm{N} 3=2.088(3), \mathrm{Co} 1-\mathrm{N} 4^{i i}=\right.$ 2.101(3) $\AA$ with ${ }^{i i}=1.5-x,-0.5+y, 0.5-z ; \mathrm{Co} 2-\mathrm{N} 8=2.117(3) \AA$ ) $)$. The Fe $-\mathrm{C}$ distances $(1.945(3)$ - 1.952(3) A) fall in the normal range for cyanido complexes of iron(III) [7], [9]. The $\left\{\mathrm{Fe}(\mathrm{CN})_{6}\right\}$ building block involves three facial cyanido groups as bridges. The three Fe-CN-Co bridges 
deviate significantly from linearity $\left(\mathrm{Co} 1-\mathrm{N} 3-\mathrm{C} 7=166.1(3), \mathrm{Co} 2-\mathrm{N} 8-\mathrm{C} 6=150.0(3), \mathrm{Co} 1^{i i i}\right.$ $-\mathrm{N} 4-\mathrm{C} 2=158.6(3)^{\circ}$ with $\left.{ }^{i i i} 0.5-x, 0.5+y, 0.5-z\right)$. Each $\left\{\mathrm{Fe}(\mathrm{CN})_{6}\right\}$ unit is connected to three cobalt ions, and each cobalt center is connected to two hexacyanido-iron(III) units, resulting into a distorted honeycomb topology (Figure 2a). The intralayer Co - Fe distances are: Fe1 $\cdots \mathrm{Co} 1=$ $\left.5.125, \mathrm{Fe} 1 \cdots \mathrm{Co} 2=4.964, \mathrm{Fe}^{i i}-\mathrm{Co} 1=5.083 \AA{ }^{i i} 1.5-\mathrm{x},-0.5+\mathrm{y}, 0.5-\mathrm{z}\right)$. The layers are paralle 1 to the $a b$ plane. Each mesh of the network contains six cobalt atoms (shared between two meshes) and six iron atoms (shared between three meshes). The deviation from the regular honeycomb topology is caused by the non-linearity of the Co-NC-Fe bridges. The stacking of the layers generates channels, which run along the crystallographic $c$ axis and host the solvent molecules (Figure 2b).

\subsection{Crystal structure of complex 2}

The asymmetric unit for compound 2, shown in Figure 3, contains two crystallographically independent heptacoordinated iron(II) ions with a pentagonal bipyramidal geometry. The $\mathrm{L}^{2}$ ligand coordinated to $\mathrm{Fe} 1$ is disordered over two positions with relative occupancy of $0.642: 0.358$. The $\mathrm{Fe}-\mathrm{N}$ distances within the equatorial plane vary between 2.076(11) and 2.355(12) $\AA$ (for Fe1), and between 2.180(6) and 2.290(5) $\AA$ (for Fe2). Each $\left\{\mathrm{Co}(\mathrm{CN})_{6}\right\}$ building-block interacts with three iron ions through meridional cyanido groups, resulting in a 2-D coordination polymer with a distorted brick wall topology (Figure 4). The distortion is due to the deviation from the linearity of the Co-CN-Fe bridges: Fe1 $-\mathrm{N} 12-\mathrm{C} 25=$ 147.4(5), Fe1 $-\mathrm{N} 13-\mathrm{C} 26=153.8(5)$ and Fe2 $-\mathrm{N} 9-\mathrm{C} 24=164.9(4)^{\circ}$. The distances between the metal ions bridged by cyanido groups are: $\mathrm{Co} 1 \cdots \mathrm{Fe} 1=5.018, \mathrm{Co} 1 \cdots \mathrm{Fe} 2=5.086, \mathrm{Co} 1 \cdots \mathrm{Fe} 1^{i}$ $=4.947 \AA(i=0.5-x,-0.5+y, 0.5-z)$. Each mesh of the network contains six cobalt ions (each one shared between three meshes) and six iron ions (each one shared between two meshes). Similarly to the case of compound $\mathbf{1}$, the stacking of the layers, parallel to the $a b$ plane, generates channels, which are filled by the solvent molecules.

Selected bond distances and angles for the two compounds are gathered in Table 1.

\subsection{Magnetic properties}

The magnetic properties of the two compounds have been investigated. The magnetic 
susceptibility shown as a $\chi T$ vs. $T$ plot for compound $\mathbf{1}$ is represented in Figure 5. The room temperature value of the $\chi T$ product, $10.8 \mathrm{~cm}^{3} \mathrm{~mol}^{-1} \mathrm{~K}$ ( $\chi$ defined as $M / H$ per $\mathrm{Co}_{3} \mathrm{Fe}_{2}$ unit), corresponds to the value expected for three high spin $\mathrm{Co}^{\mathrm{II}}$ and two low spin $\mathrm{Fe}^{\mathrm{III}}$ non-interacting magnetic centers $\left(10.8 \mathrm{~cm}^{3} \mathrm{~mol}^{-1} \mathrm{~K}\right.$ with $\left.g_{\mathrm{Co}}=g_{\mathrm{Fe}}=2.6\right)$, having in mind that both high spin $\mathrm{Co}^{\mathrm{II}}$ and low spin $\mathrm{Fe}^{\mathrm{III}}$ ions are characterized by a significant orbital contribution to their magnetic moment. By decreasing the temperature, $\chi T$ product increases slowly, then more abruptly until reaching $71 \mathrm{~cm}^{3} \mathrm{~mol}^{-1} \mathrm{~K}$ at $2.7 \mathrm{~K}$, indicating dominant ferromagnetic interactions between the $\mathrm{Co}^{\mathrm{II}}$ and $\mathrm{Fe}^{\mathrm{III}}$ ions through the cyanido bridges. The exchange interaction between high spin $\mathrm{Co}^{\mathrm{II}}$ and low spin $\mathrm{Fe}^{\mathrm{III}}$ ions within cyanido-bridged complexes is frequently ferromagnetic [15], and in fewer cases it was also found to be antiferromagnetic [16]. Below $2.7 \mathrm{~K}, \chi T$ decreases due to a saturation associated to the long-range magnetic order (vide infra). The field dependence of the magnetization recorded between 1.8 and $8 \mathrm{~K}$ is shown Figure 6. The magnetization reaches 10.7 $\mu_{\mathrm{B}}$ at $1.85 \mathrm{~K}$ under $7 \mathrm{~T}$. Below $3 \mathrm{~K}$, the magnetization increases very fast at low field, indicating the occurrence of a magnetic order. This magnetic order appears to be ferromagnetic, as no inflection point (that could be related to an antiferromagnetic interactions and thus antiferromagnetic order) is seen on the $M$ vs. $H$ plot. Moreover, the ferromagnetic order is also in agreement with the increase of the $\chi T$ vs $T$ data discussed above. This magnetic order is further confirmed by the ac measurements displaying (i) out-of-phase susceptibility $\chi^{\prime \prime}$ different to zero below $3 \mathrm{~K}$ and (ii) no significant frequency dependence of the in-phase $\chi$ and $\chi^{\prime \prime}$ components, as seen on the data shown in Figure 7. The absence of an inflection point on the $M$ vs $H$ curve, even at low fields, and the out-of-phase signal below $3 \mathrm{~K}$ strongly suggest that the interlayer interaction is ferromagnetic.

The temperature dependence of the $\chi T$ product for compound 2 at 1000 Oe is presented in Figure 8. The magnetic contribution for 2 is due solely to the high spin $\mathrm{Fe}^{\mathrm{II}}$ ions, and the room temperature value of $10.9 \mathrm{~cm}^{3} \mathrm{~mol}^{-1} \mathrm{~K}$ corresponds exactly to the expected values for three $S=2$ $\mathrm{Fe}^{\mathrm{II}}$ ions per formula unit with $g_{\mathrm{Fe}}=2.2$. The $\chi T$ product remains constant down to ca $40 \mathrm{~K}$, then is decreases abruptly, because of the quite strong ZFS effect associated to the iron(II) ion within this stereochemistry [6]. Intralayer antiferromagnetic interactions between the $\mathrm{Fe}^{\mathrm{II}}$ nodes, if any, are very weak because of the quite long Fe $\cdots$ Fe distances (7.699 and $7.514 \AA$ ). The presence of the magnetic anisotropy is confirmed by the non-superposition of the $M$ vs. $H / T$ curves (Figure 8). Consequently, the magnetic data of $\mathbf{2}$ have been fitted using the following Hamiltonian: 


$$
\mathbf{H}=D \cdot \boldsymbol{S}_{\mathrm{Z}}^{2}
$$

The theoretical susceptibility calculated from this Hamiltonian fits quite well and simultaneously the $\chi T$ vs. $T$ and $M$ vs $H / T$ data of 2 (solid lines in Figure 8) leading to $D / k_{\mathrm{B}}=-5.5 \mathrm{~K}$ and $g=$ 2.21(5).

The magnetic properties of $\mathbf{1}$ and $\mathbf{2}$ are strongly affected by the nature of the hexacyanidometallate bridging unit, either paramagnetic $\left(S_{\mathrm{Fe}(\mathrm{III})}=1 / 2\right)$ for compound $\mathbf{1}$ or diamagnetic $\left(S_{\mathrm{Co}(\mathrm{III})}=0\right)$, resulting in a ferromagnetically ordered phase below $3 \mathrm{~K}$ for $\mathbf{1}$ or a paramagnetic state even at low temperatures for 2.

\section{Conclusions}

In summary, we described two new cyanido-bridged 2-D coordination polymers constructed from $\left[\mathrm{M}(\mathrm{CN})_{6}\right]^{3-}$ spacers and pentagonal bipyramidal complex cations acting as structuring nodes. The two compounds show honeycomb versus brick-wall network topologies observed for the first time for these types of building blocks. These two examples illustrate also the robustness of the precursors, obtained using the pentadentate macrocyclic ligands $\mathrm{L}^{1}$ and $\mathrm{L}^{2}$, acting as network nodes. The magnetic properties of complex $\mathbf{1}$ are interesting, as this compound displays a ferromagnetically ordered state below $3 \mathrm{~K}$.

\section{Appendix A. Supplementary data}

CCDC 984790 and 960771 contain the supplementary crystallographic data for compounds 1 and 2. These data can be obtained free of charge via http://www.ccdc.cam.ac.uk/conts/retrieving.html, or from the Cambridge Crystallographic Data Centre, 12 Union Road, Cambridge CB2 1EZ, UK; fax: +44 1223336 033; or e-mail: deposit@ccdc.cam.ac.uk.

\section{Acknowledgements.}

We are grateful to the UEFISCDI (project PN-II-ID-JRP-RO-FR-2011-2-0034), University of Bordeaux, the CNRS, the Aquitaine Région, the IUF (Institut Universitaire de France) and the ANR (ANR-12-IS07-0004, CREMM project) for financial support. 


\section{References}

[1] (a) T. Mallah, S. Thiébaut, M. Verdaguer, P. Veillet, Science, 262 (1993) 1554; (b) S.

Ferlay, T. Mallah, R. Ouahès, P. Veillet, M. Verdaguer, Nature 378 (1995) 701.

[2] M. Ohba, N. Maruono, H. Okawa, T. Enoki, J.M. Latour, J. Am. Chem. Soc. 116 (1994) 11566.

[3] Several excellent reviews on heterometallic complexes constructed using hexacyanido metalloligands have been published: (a) K. R. Dunbar, R. A. Heintz, Progr. Inorg. Chem. 45 (1997) 283; (b) M. Verdaguer, A. Bleuzen, V. Marvaud, J. Vaissermann, M. Seuleiman, C. Desplanches, A. Scuiller, C. Train, R. Garde, G. Gelly, C. Lomenech, I. Rosenman, P. Veillet, C. Cartier, F. Villain, Coord. Chem.Rev. 190-192 (1999) 1023; (c) M. Ohba, H. Okawa, Coord. Chem. Rev. 198 (2000) 313; (d) J. Černák, M. Orendáč, I. Potočňák, J. Chomič, A. Orendáčová, J. Skoršepa, A. Feher, Coord. Chem. Rev. 224 (2002) 51; (d) M. Shratuk, C. Avendano, K. R. Dunbar, Progr. Inorg. Chem. 56 (2009) 155 .

[4] See for example: (a) S. Ferlay, T. Mallah, J. Vaissermann, F. Bartolomé, P. Veillet, M. Verdaguer, Chem. Commun. (1996) 2481; (b) E. Colacio, J. M. Dominguez-Vera, M. Ghazi, R. Kivekas, F. Lloret, J. M. Moreno, H. Soeckli-Evans, Chem. Commun. (1999) 987; (c) A. Marvilliers, S. Parsons, E. Rivière, J.-P. Audière, M. Kurmoo, T. Mallah, Eur. J. Inorg. Chem. (2001) 1287.

[5] See for example: H. Z. Kou, S. Gao, B. Q. Ma, D. Z. Liao, Chem. Commun. (2000) 1309.

[6] (a) T. S. Venkatakrishnan, S. Sahoo, N. Bréfuel, C. Duhayon, C. Paulsen, A.-L. Barra, S. Ramasesha, J.-P. Sutter, J. Am. Chem. Soc. 132 (2010) 6047; (b) Y.-Z. Zhang, B.-W. Wang, O. Sato, S. Gao, Chem. Commun. 46 (2010) 6959.

[7] S. Tanase, M. Andruh, N. Stanica, C. Mathonière, G. Rombaut, S. Golhen, L. Ouahab, Polyhedron 22 (2003) 1315.

[8] C. Paraschiv, M. Andruh, Y. Journaux, Z. Žak, N. Kyritsakas, L. Ricard, J. Mater. Chem. 16 (2006) 2660. 
[9] F. Bonadio, M.-C. Senna, J. Ensling, A. Sieber, A. Neels, H. Stoeckli-Evans, S. Decurtins, Inorg. Chem. 44 (2005) 969.

[10] Y.-Z. Zhang, O. Sato, Inorg. Chem. 49 (2010) 1271.

[11] Oxford Diffraction, CrysAlis CCD and CrysAlis RED, Oxford Diffraction Ltd., Abingdon, Oxfordshire, England, 2007.

[12] G. M. Sheldrick, SHELXL-97; Program for Crystal Structure Refinement, University of Göttingen, 1997.

[13] A. Altomare, M. C. Burla, M. Camalli, G. L. Cascarano, C. Giacovazzo, A. Guagliardi, A. G. G. Moliterni, G. Polidori, R. Spagna, J. Appl. Cryst. 32 (1999) 115.

[14] A. L. Spek, PLATON. A multipurpose Crystallographic Tool. Utrecht University, The Netherlands.

[15] (a) R. Lescouëzec, J. Vaissermann, C. Ruiz-Pérez, F. Lloret, R. Carrasco, M. Julve, M. Verdaguer, Y. Dromzee, D. Gatteschi, W. Wernsdorfer, Angew. Chem., Int. Ed. 42 (2003) 1483; (b) L. M. Toma, R. Lescouëzec, F. Lloret, M. Julve, J. Vaissermann, M. Verdaguer, Chem. Commun. (2003), 1850; (c) Z.-G. Gu, Q.-F. Yang, W. Liu, Y. Song, Y.-Z. Li, J.-L. Zuo, X.-Z. You, Inorg. Chem. 45 (2006) 8895; (d) J. Kim, S. Han, K. I. Pokhodyna, J. M. Migliori, J. S. Miller, Inorg. Chem. 44 (2005) 6983; (e) E. Pardo, M. Verdaguer, P. Herson, H. Rousselière, J. Cano, M. Julve, F. Lloret, R. Lescouëzec, Inorg. Chem. 50 (2011) 6250; (f) H. Tchouka, A. Meetsma, W. R. Browne, Inorg. Chem. 49 (2010) 10557; (g) D.-P. Dong, J.-Q. Xiao, P.-F. Zhuang, H. Zheng, L. Zhao, C. He, T. Liu, C.-Y. Duan, Inorg. Chem. Commun. 21 (2012) 84.

[16] D. Li, S. Parkin, G. T. Yee, A. V. Prosvirin, S. M. Holmes, Inorg. Chem. 44 (2005) 4903. 


\section{CAPTION OF THE FIGURES}

Figure 1. Perspective view of the asymmetric unit of compound $1(i=1-x, y, 0.5-z)$.

Figure 2. (a) View along the crystallographic $c$ axis of the coordination polymer 1. (b) Packing diagram showing the formation of the channels containing the solvent molecules. The macrocyclic ligands coordinated to the cobalt ions (pink) have been removed for the sake of clarity.

Figure 3. Perspective view of the asymmetric unit of compound 2.

Figure 4. View along the crystallographic $c$ axis of the coordination polymer $\mathbf{2}$ showing only the major component of the disordered macrocyclic complex for the sake of clarity.

Figure 5. Temperature dependence of the $\chi T$ product at $1000 \mathrm{Oe}$ (with $\chi$ defined as the molar magnetic susceptibility equal to $M / H$ ) for compound 1; Inset: enlarged view of the main figure emphasizing the high temperature behaviour of the $\chi T$ product.

Figure 6. Field dependence of the magnetization for 1, recorded at different temperatures.

Figure 7. Temperature dependence below $10 \mathrm{~K}$ of the in-phase $(\chi$, top) and out-of-phase $(\chi$, bottom) components of the $a c$ susceptibility at different frequencies between 1 and $1000 \mathrm{~Hz}$ with a 3 Oe $a c$-field in zero $d c$-field for compound 2 . Solid lines are guides for eyes. 
Figure 8. Temperature dependence of the $\chi T$ product at 1000 Oe (with $\chi$ defined as the molar magnetic susceptibility equal to $M / H$ ) for compound 2 ; Inset: $M$ vs. $H$ plots at different temperatures below $8 \mathrm{~K}$. The solid lines are representing the best simulation of the experimental data as described in the text. 

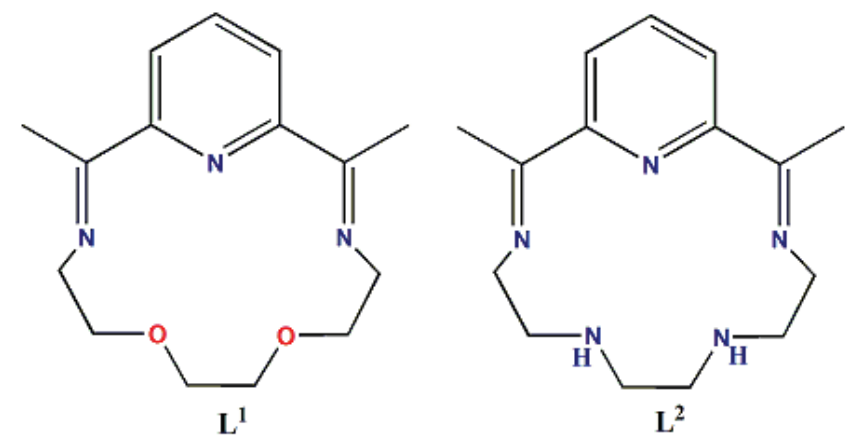

Scheme 1

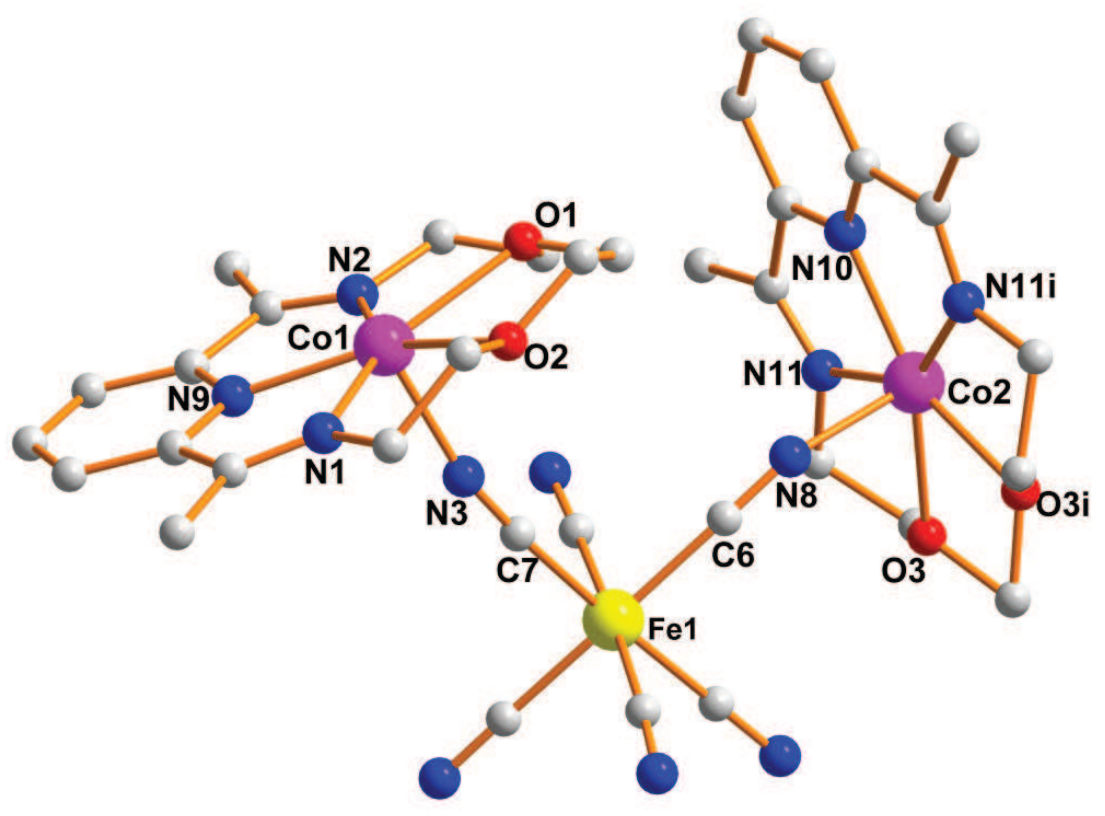

Figure 1 


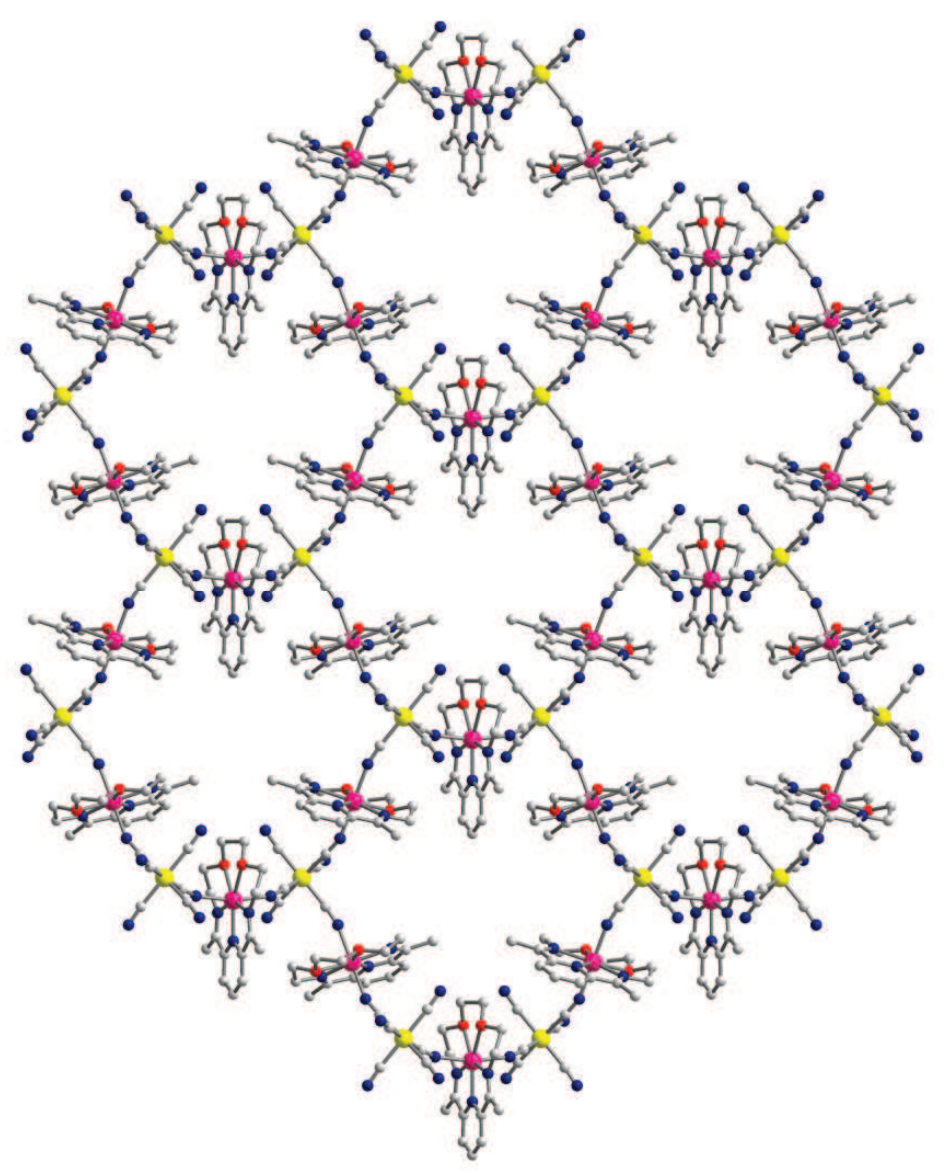

(a) 


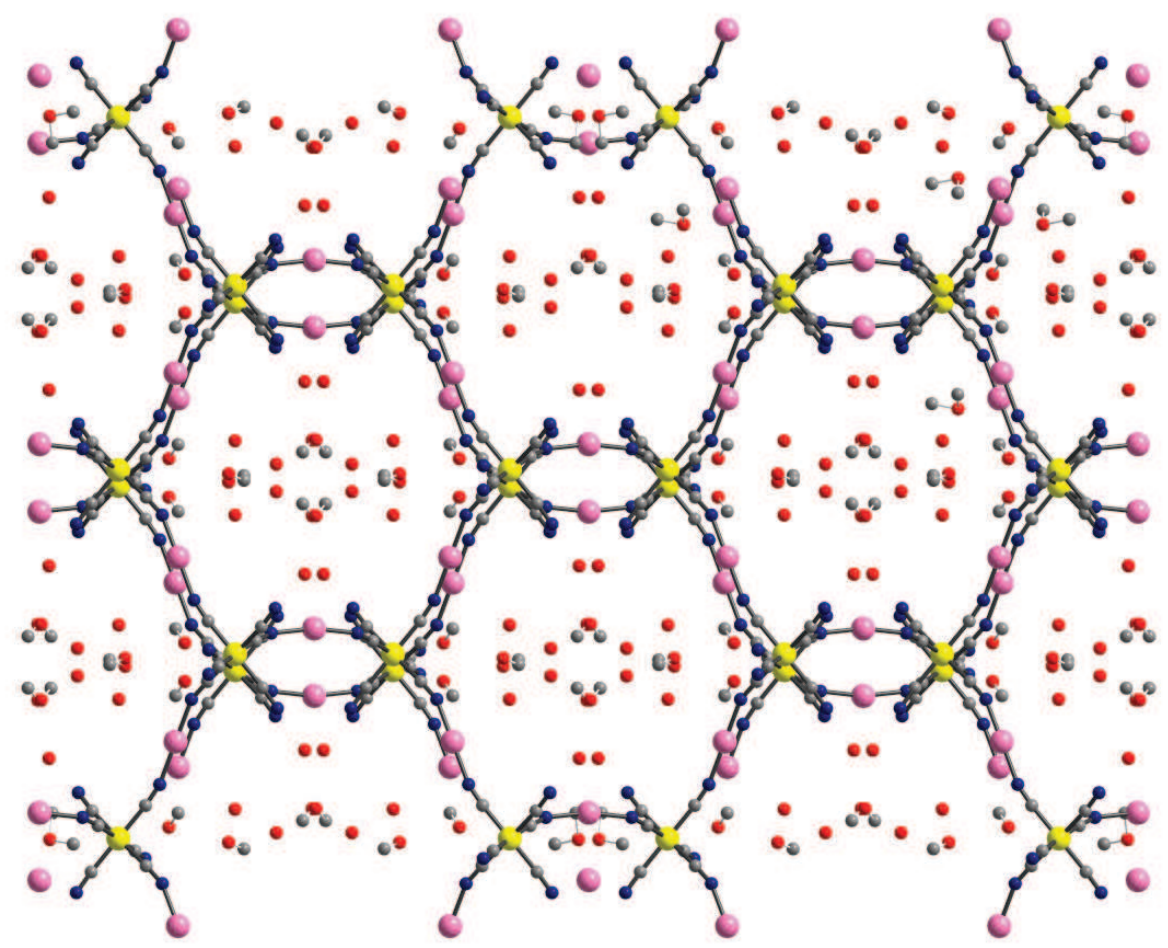

(b)

Figure 2

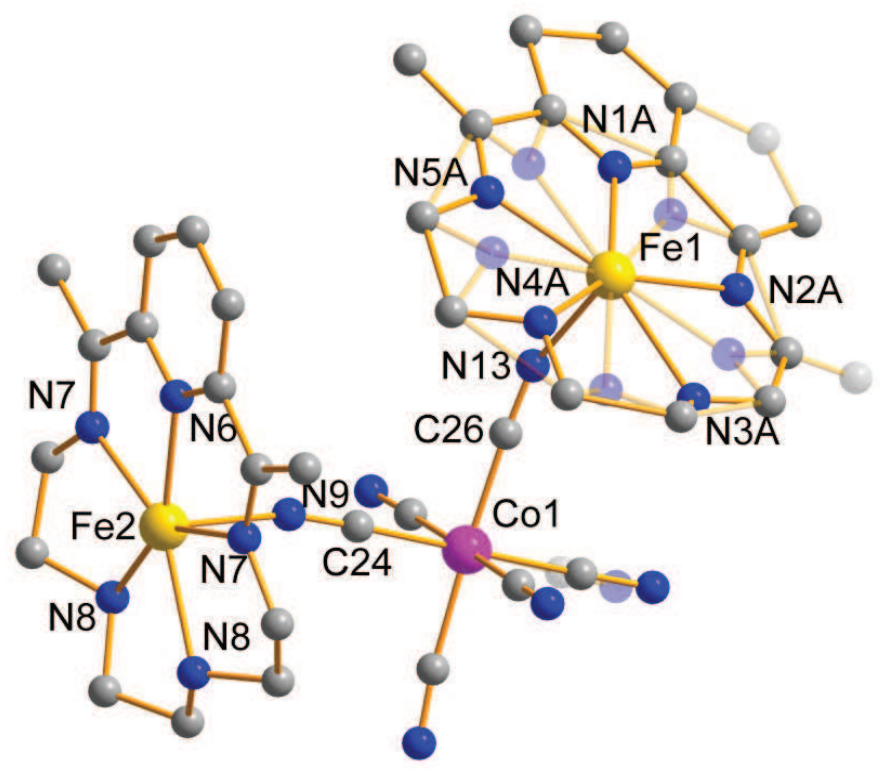

Figure 3 


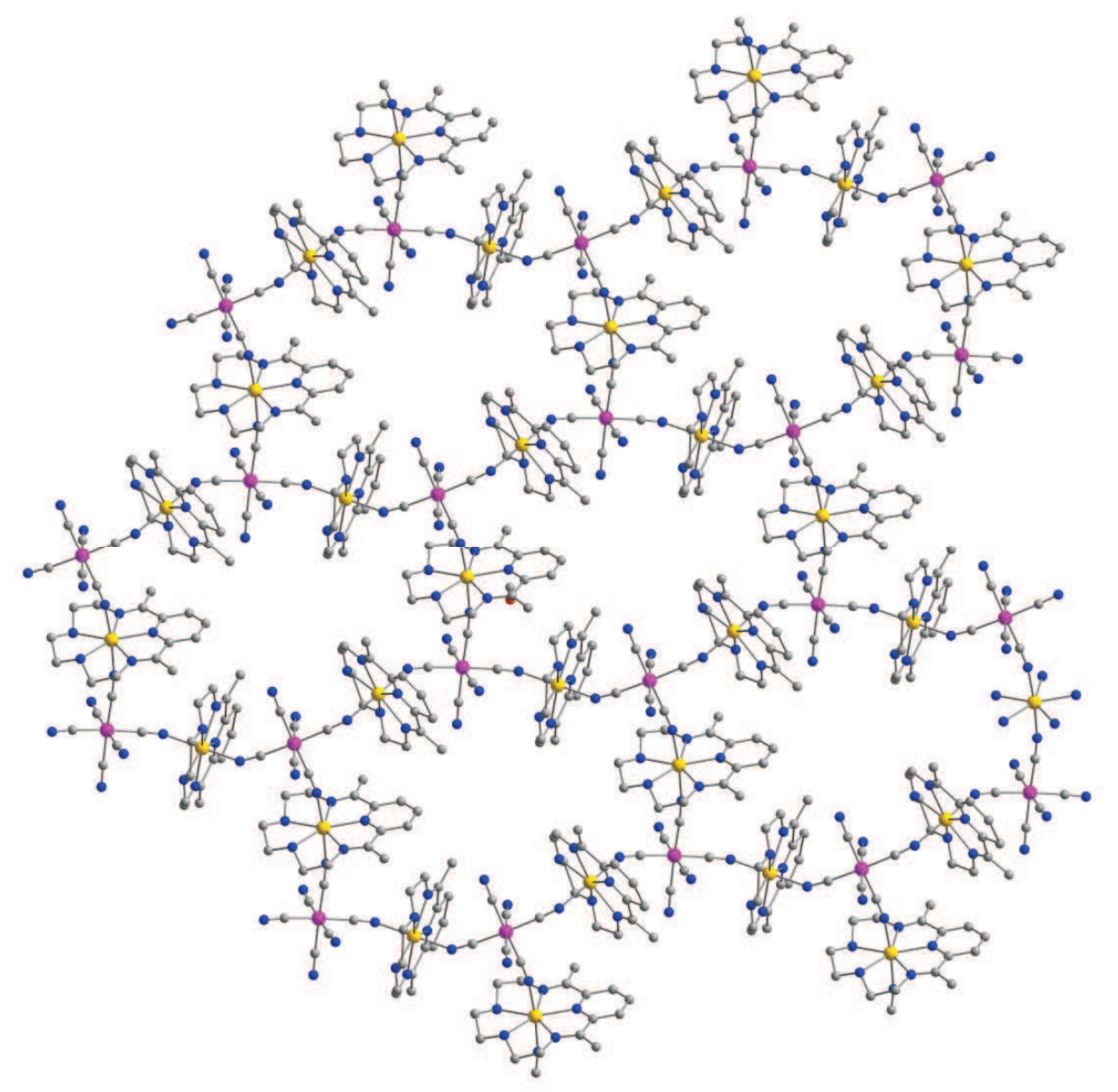

Figure 4

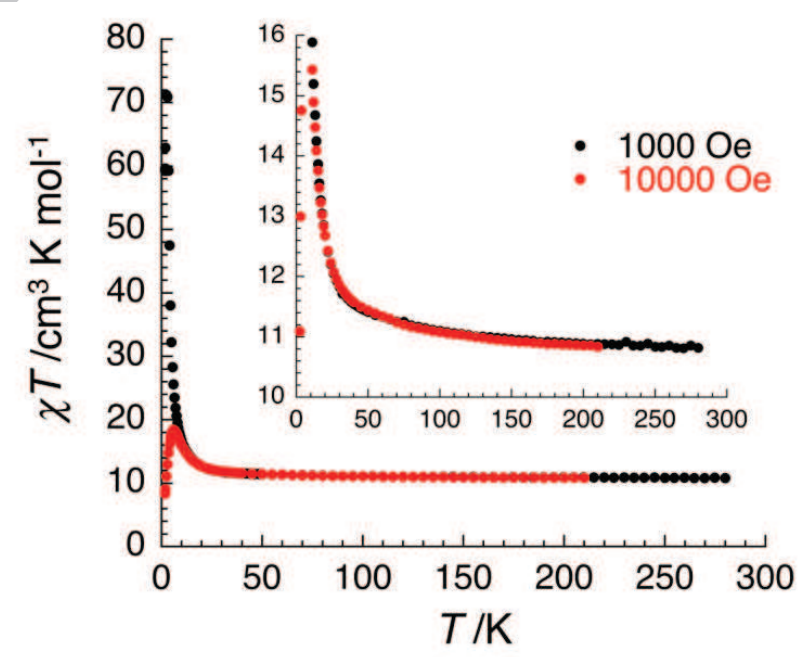


Figure 5

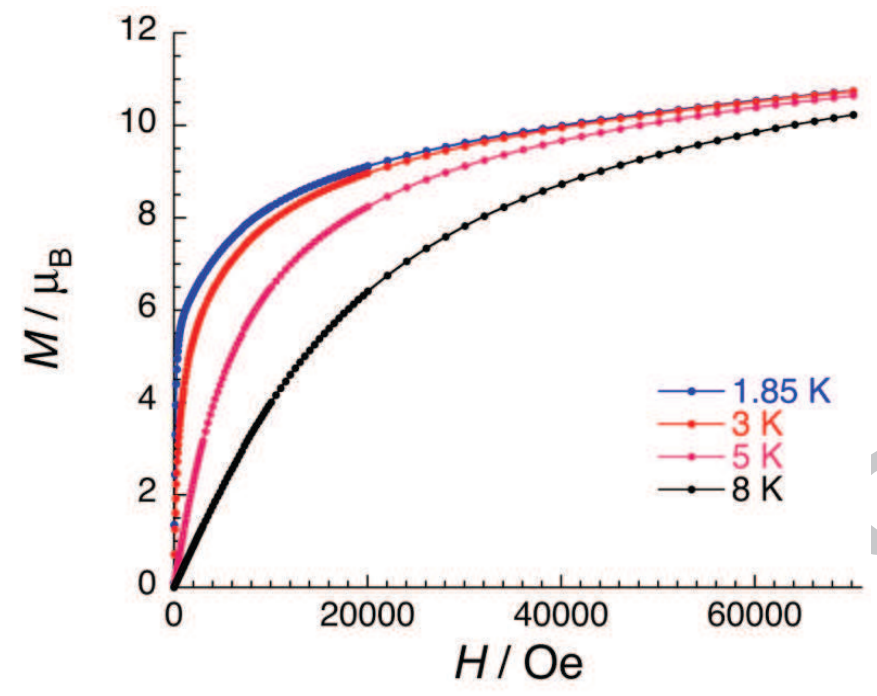

Figure 6 


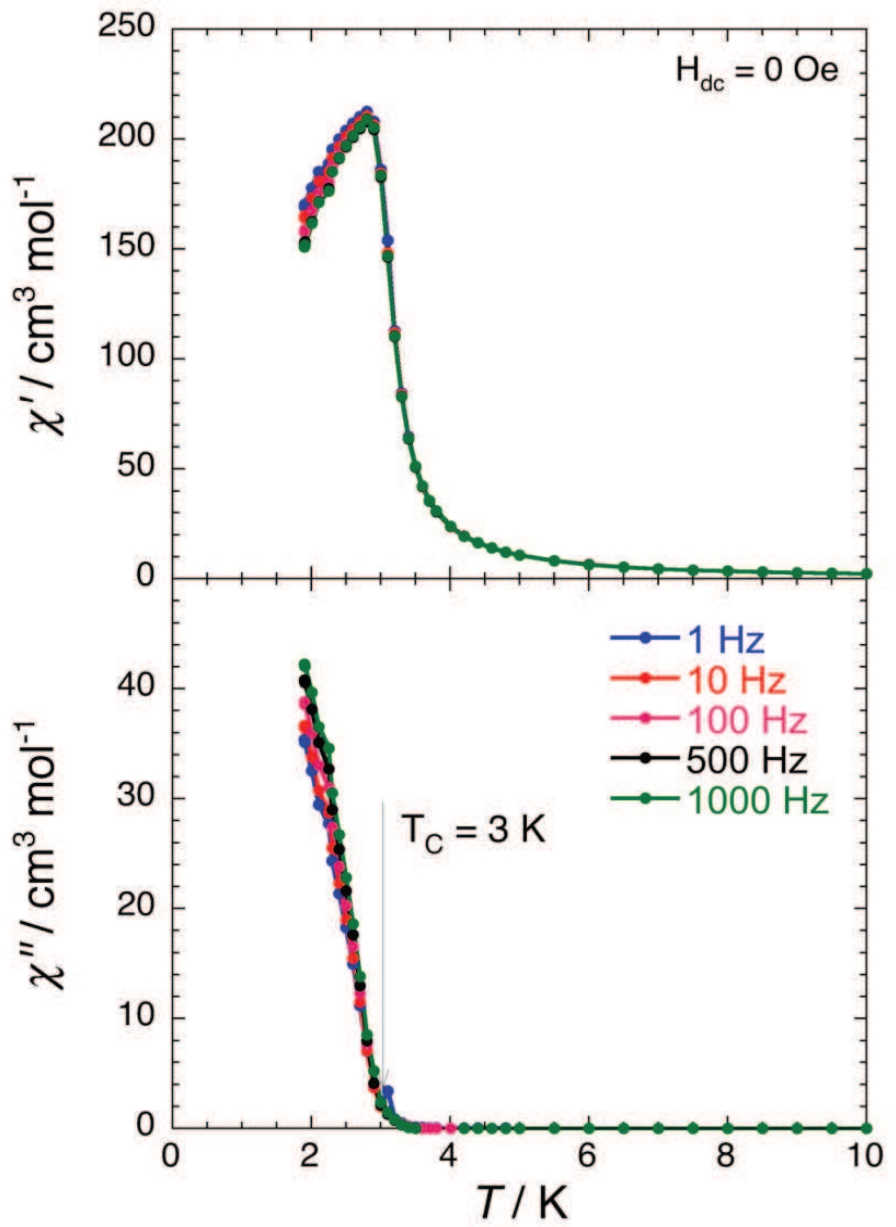

Figure 7 


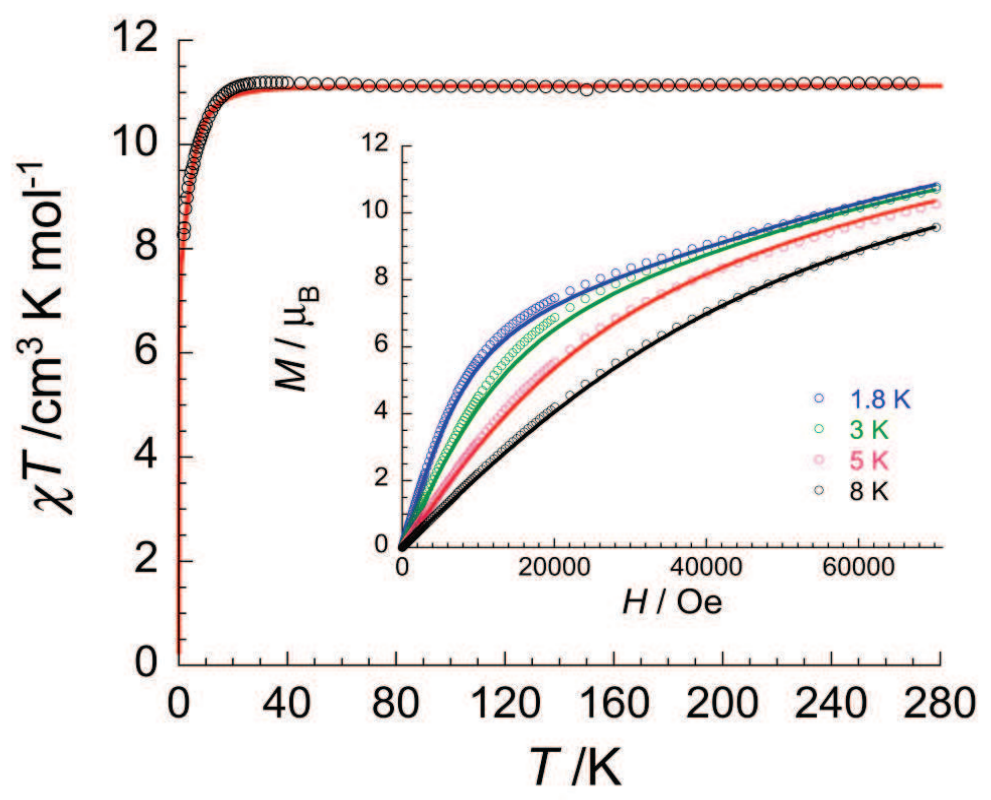

Figure 8 
Table 1. Selected bond lengths $(\AA)$ and angles $\left(^{\circ}\right)$ in compounds $\mathbf{1}$ and $\mathbf{2}$.

\begin{tabular}{|c|c|c|c|c|}
\hline Compound & 1 & & 2 & \\
\hline $\begin{array}{l}\text { Bond } \\
\text { lengths } \\
(\AA)\end{array}$ & $\begin{array}{l}\mathrm{Co} 1-\mathrm{N} 1=2.182(3) \\
\mathrm{Co} 1-\mathrm{O} 2=2.275(3) \\
\mathrm{Co} 1-\mathrm{O} 1=2.318(3) \\
\mathrm{Co} 1-\mathrm{N} 2=2.186(3) \\
\mathrm{Co} 1-\mathrm{N} 9=2.117(3) \\
\mathrm{Co} 1-\mathrm{N} 3=2.088(3) \\
\mathrm{Co} 1-\mathrm{N} 4{ }^{i i}=2.101(3) \\
- \\
\mathrm{Fe} 1-\mathrm{C} 7=1.947(3) \\
\mathrm{Fe} 1-\mathrm{C} 5=1.946(3) \\
\mathrm{Fe} 1-\mathrm{C} 4=1.952(3) \\
\mathrm{Fe} 1-\mathrm{C} 6=1.945(3)\end{array}$ & $\begin{array}{l}\text { Co2-N8 }=2.117(3) \\
\text { Co2-O3 }=2.257(2) \\
\text { Co2-N10 }=2.127(4) \\
\text { Co2-N11 }=2.195(3)\end{array}$ & $\begin{array}{l}\text { Fe1-N1A }=2.238(10) \\
\text { Fe1-N2A }=2.326(13) \\
\text { Fe1-N3A }=2.355(12) \\
\text { Fe1-N4A }=2.285(10) \\
\text { Fe1-N5A }=2.250(11) \\
\text { Fe1-N13 }=2.157(5) \\
\text { Fe1-N12 }=2.152(4) \\
- \\
\text { Co1-C28 }=1.883(9) \\
\text { Co1-C26 }=1.888(6) \\
\text { Co1-C29A }=1.875(15) \\
\text { Co1-C25 }=1.894(6) \\
\text { Co1-C27 }=1.892(8) \\
\text { Co1-C24 }=1.859(6)\end{array}$ & $\begin{array}{l}\text { Fe2-N6 }=2.180(6) \\
\text { Fe2-N8 }=2.290(5) \\
\text { Fe2-N7 }=2.236(5) \\
\text { Fe2-N9 }=2.142(5)\end{array}$ \\
\hline 1 & $\begin{array}{l}\text { N2-Co1-N9 }=73.23(13) \\
\text { N9-Co1-N1 }=72.83(13) \\
\text { N1-Co1-O2 }=72.60(12) \\
\text { O2-Co1-O1 }=70.29(10) \\
\text { O1-Co1-N2 }=71.27(12) \\
\text { N9-Co1-O2 }=145.46(12) \\
\text { N1-Co1-O1 }=142.72(12) \\
\text { N2-Co1-O2 }=141.31(12) \\
\text { N2-Co1-N1 }=146.00(12) \\
\text { N9-Co1-O1 }=143.94(12) \\
\text { N3-Co1-N4 }{ }^{i i}=174.49(12) \\
\text { N3-Co1-N9 }=96.63(11) \\
\text { N3-Co1-N2 }=89.33(12) \\
\text { N3-Co1-O1 }=89.12(10) \\
\text { N3-Co1-O2 }=85.89(11) \\
\text { N3-Co1-N1 }=91.74(11) \\
\text { N4 }{ }^{i i}-\mathrm{Co} 1-\mathrm{N} 9=88.49(11) \\
\text { N4 }{ }^{i i}-\mathrm{Co} 1-\mathrm{N} 2=94.09(12) \\
\text { N4 }{ }^{i i}-\mathrm{Co} 1-\mathrm{O} 1=87.90(10) \\
\mathrm{N} 4{ }^{i i}-\mathrm{Co} 1-\mathrm{O} 2=88.75(11) \\
\mathrm{N} 4{ }^{i i}-\mathrm{Co} 1-\mathrm{N} 1=87.84(11) \\
- \\
\mathrm{C} 6-\mathrm{Fe} 1-\mathrm{C} 4=86.61(13) \\
\mathrm{C} 4-\mathrm{Fe} 1-\mathrm{C} 2=85.44(14) \\
\mathrm{C} 2-\mathrm{Fe} 1-\mathrm{C} 3=86.38(14) \\
\mathrm{C} 3-\mathrm{Fe} 1-\mathrm{C} 7=92.32(14) \\
\mathrm{C} 7-\mathrm{Fe} 1-\mathrm{C} 5=85.76(14) \\
\mathrm{C} 5-\mathrm{Fe} 1-\mathrm{C} 6=84.05(13) \\
\mathrm{C} 6-\mathrm{Fe} 1-\mathrm{C} 2=98.48(13) \\
\mathrm{C} 6-\mathrm{Fe} 1-\mathrm{C} 3=174.24(14) \\
\mathrm{C} 6-\mathrm{Fe} 1-\mathrm{C} 7=90.53(13) \\
\mathrm{C} 5-\mathrm{Fe} 1-\mathrm{C} 4=96.14(14) \\
\mathrm{C} 5-\mathrm{Fe} 1-\mathrm{C} 3=91.17(14) \\
\mathrm{C} 5-\mathrm{Fe} 1-\mathrm{C} 2=177.11(13)\end{array}$ & $\begin{array}{l}\text { N10-Co2-N11 }{ }^{i}=72.68(8) \\
\text { N11 }{ }^{i}-\mathrm{Co} 2-\mathrm{O} 3^{i}=71.85(10) \\
\mathrm{O}^{i}-\mathrm{Co} 2-\mathrm{O} 3=70.98(12) \\
\mathrm{N} 10-\mathrm{Co} 2-\mathrm{O} 3=144.51(6) \\
\mathrm{N} 11-\mathrm{Co} 2-\mathrm{O} 3^{i}=142.79(10) \\
\mathrm{N} 11-\mathrm{Co} 2-\mathrm{N} 11^{i}=145.36(16) \\
\mathrm{N} 8 \mathrm{i}-\mathrm{Co} 2-\mathrm{N} 8=168.59(16) \\
\mathrm{N} 8-\mathrm{Co} 2-\mathrm{N} 10=95.72(9) \\
\mathrm{N} 8-\mathrm{Co} 2-\mathrm{N} 11^{i}=91.15(10) \\
\mathrm{N} 8-\mathrm{Co} 2-\mathrm{O} 3^{i}=84.64(10) \\
\mathrm{N} 8-\mathrm{Co} 2-\mathrm{O} 3=86.08(10) \\
\mathrm{N} 8-\mathrm{Co} 2-\mathrm{N} 11=92.25(10) \\
\mathrm{Co} 1-\mathrm{N} 3-\mathrm{C} 7=166.1(3) \\
\mathrm{Co} 1^{i i i}-\mathrm{N} 4-\mathrm{C} 2=158.6(3) \\
\mathrm{Co} 2-\mathrm{N} 8-\mathrm{C} 6=150.0(3)\end{array}$ & $\begin{array}{l}\text { N1A-Fe1-N5A }=72.0(4) \\
\text { N5A-Fe1-N4A }=72.5(4) \\
\text { N4A-Fe1-N3A }=75.3(4) \\
\text { N3A-Fe1-N2A }=71.2(6) \\
\text { N2A-Fe1-N1A }=69.6(5) \\
\text { N2A-Fe1-N5A }=141.4(5) \\
\text { N5A-Fe1-N3A }=147.3(5) \\
\text { N4A-Fe1-N1A }=143.6(4) \\
\text { N4A-Fe1-N2A }=145.9(5) \\
\text { N3A-Fe1-N1A }=140.7(5) \\
\text { N13-Fe1-N12 }=171.70(18) \\
\text { N13-Fe1-N1A }=95.9(2) \\
\text { N13-Fe1-N5A }=88.5(2) \\
\text { N13-Fe1-N4A }=90.7(3) \\
\text { N13-Fe1-N3A }=86.7(3) \\
\text { N13-Fe1-N2A }=93.0(3) \\
\text { N12-Fe1-N1A }=92.3(2) \\
\text { N12-Fe1-N2A }=91.4(3) \\
\text { N12-Fe1-N3A }=88.1(3) \\
\text { N12-Fe1-N4A }=81.7(3) \\
\text { N12-Fe1-N5A }=92.4(2) \\
- \\
\text { C28-Co1-C26 }=88.8(3) \\
\text { C26-Co1-C24 }=90.7(2) \\
\text { C24-Co1-C27 }=85.8(3) \\
\text { C27-Co1-C25 }=92.4(2) \\
\text { C25 }-\mathrm{Co} 1-C 29 A=90.5(3) \\
\text { C29A-Co1-C28 }=83.6(6) \\
\text { C28-Co1-C24 }=92.0(3) \\
\text { C28-Co1-C27 }=177.8(4) \\
\text { C28-Co1-C25 }=87.3(3) \\
\text { C26-Co1-C27 }=91.6(2) \\
\text { C26-Co1-C25 }=176.0(3) \\
\text { C26-Co1-C29A = 88.1(4) }\end{array}$ & $\begin{array}{l}\text { N6-Fe2-N7 }=70.76(13) \\
\text { N7-Fe2-N8 }=72.24(19) \\
\text { N8 }-\mathrm{Fe} 2-\mathrm{N} 8=74.5(3) \\
\text { N6-Fe2-N8 }=142.77(14) \\
\text { N7 }^{i}-\mathrm{Fe} 2-\mathrm{N} 7=141.5(3) \\
\text { N7-Fe2-N8 }=146.1(2) \\
\text { N9 }-\mathrm{Fe} 2-\mathrm{N} 9=174.3(2) \\
\text { N9-Fe2-N6 }=92.83(12) \\
\text { N9-Fe2-N7 }=94.98(18) \\
\text { N9-Fe2-N8 }=86.36(18) \\
\text { N9-Fe2-N8 }=89.14(18) \\
\text { N9-Fe2-N7 }{ }^{i}=86.89(19) \\
\text { Fe1-N12-C25 }=147.4(5) \\
\text { Fe1-N13-C25 }=153.8(5) \\
\text { Fe2-N9-C24 }=164.9(4)\end{array}$ \\
\hline
\end{tabular}

\footnotetext{
${ }^{i}=1-\mathrm{x}, \mathrm{y}, 0.5 \mathrm{z}$

${ }^{i i}=1.5-\mathrm{x},-0.5+\mathrm{y}, 0.5-\mathrm{z}$

${ }^{i i i}=1.5-\mathrm{x}, 0.5+\mathrm{y}, 0.5-\mathrm{z}$
}

$$
\begin{aligned}
& { }^{i}=-\mathrm{x}, \mathrm{y}, 0.5-\mathrm{z} \\
& { }^{i i}=0.5-\mathrm{x},-0.5+\mathrm{y}
\end{aligned}
$$


Table 2. Crystallographic data, details of data collection and structure refinement parameters for compounds $\mathbf{1}$ and $\mathbf{2}$.

\begin{tabular}{|c|c|c|}
\hline$\overline{\text { Compound }}$ & 1 & 2 \\
\hline Chemical formula & $\mathrm{C}_{63} \mathrm{H}_{99} \mathrm{Co}_{3} \mathrm{Fe}_{2} \mathrm{~N}_{21} \mathrm{O}_{18}$ & $\mathrm{C}_{59} \mathrm{H}_{103} \mathrm{Co}_{2} \mathrm{Fe}_{3} \mathrm{~N}_{27} \mathrm{O}_{15}$ \\
\hline$M\left(\mathrm{~g} \mathrm{~mol}^{-1}\right)$ & 1727.12 & 1716.06 \\
\hline Temperature, $(\mathrm{K})$ & $173(2)$ & $100(2)$ \\
\hline Wavelength, $(\AA)$ & 0.71073 & 0.71073 \\
\hline Crystal system & Monoclinic & Monoclinic \\
\hline Space group & $\mathrm{C} 2 / \mathrm{c}$ & $\mathrm{C} 2 / \mathrm{c}$ \\
\hline$a(\AA)$ & $26.3472(3)$ & $26.4011(10)$ \\
\hline$b(\AA)$ & $16.6908(4)$ & $18.6423(6)$ \\
\hline$c(\AA)$ & $19.5461(5)$ & $20.2408(10)$ \\
\hline$\alpha\left(^{\circ}\right)$ & 90 & $90<2$ \\
\hline$\beta\left(^{\circ}\right)$ & $108.890(2)$ & $113.497(7)$ \\
\hline$\left.x^{\circ}\right)$ & 90 & 90 \\
\hline$V\left(\AA^{3}\right)$ & $8132.6(3)$ & \\
\hline $\mathrm{Z}$ & 4 & 4 \\
\hline$D_{\mathrm{c}}\left(\mathrm{g} \mathrm{cm}^{-3}\right)$ & 1.411 & 1.408 \\
\hline$\mu\left(\mathrm{mm}^{-1}\right)$ & 1.023 & 1.000 \\
\hline $\mathrm{F}(000)$ & 3604 & 3592 \\
\hline Goodness-of-fit on $F^{2}$ & 1.036 & 0.802 \\
\hline Final $R_{1}{ }^{a}, w R_{2}{ }^{b}[I>2 \sigma(I)]$ & $0.0469,0.1274$ & $0.0656,0.1639$ \\
\hline$R_{1}{ }^{a}, w R_{2}^{b}$ (all data) & $0.0555,0.1221$ & $0.1639,0.1883$ \\
\hline Largest diff. peak and hole $\left(\mathrm{e} \AA^{-3}\right)$ & $0.874,-0.671$ & $0.741,-0.402$ \\
\hline
\end{tabular}

${ }^{\mathrm{a}} R_{1}=\sum|| F_{o}|-| F_{c}|| \sum \sum\left|F_{o}\right| .{ }^{b} w R_{2}=\left[\sum w\left(F_{o}{ }^{2}-F_{c}^{2}\right)^{2} / \sum w\left(F_{o}{ }^{2}\right)^{1 / 2} ; w=1 /\left[\sigma^{2}\left(F_{0}{ }^{2}\right)+(a P)^{2}+b P\right]\right.$ whereP= $\left[\max \left(F_{0}{ }^{2}, 0\right)+2 F_{c}{ }^{2}\right] / 3$. 

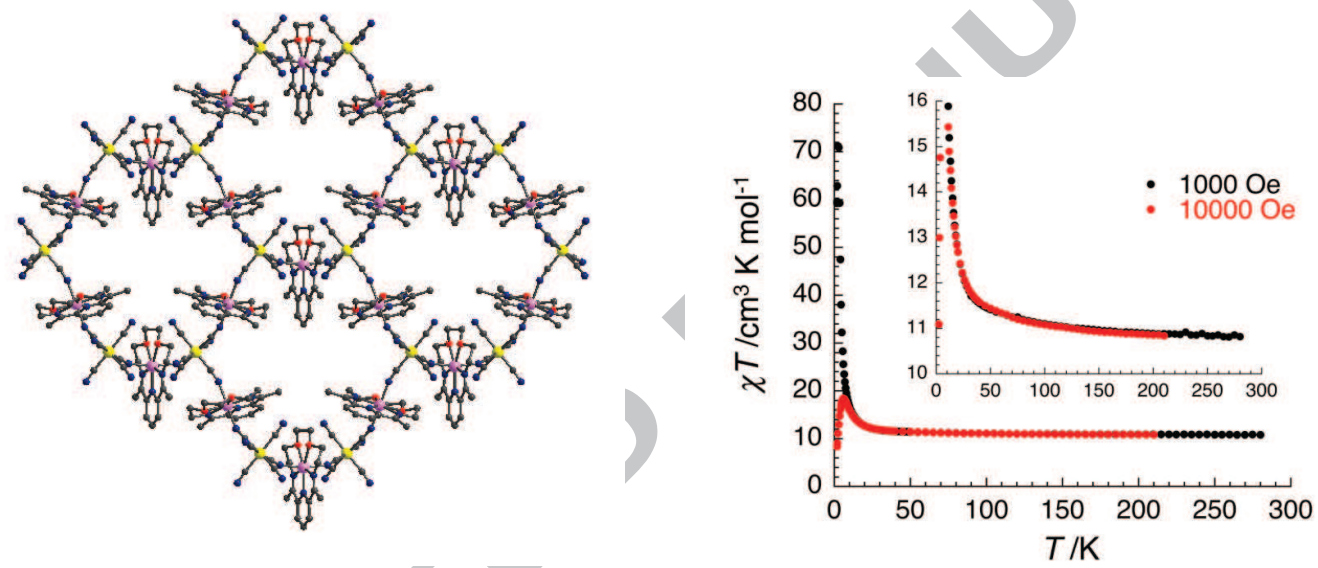

New

bidimensional cyanido-bridged heterometallic

coordination polymers, $\left[\mathrm{Co}_{3}{ }_{3} \mathrm{Fe}^{\mathrm{III}} 2\right]$ and $\left[\mathrm{Fe}_{3}^{\mathrm{II}} \mathrm{Co}_{2}{ }_{2}^{\mathrm{III}}\right]$, have been assembled following the building-block approach. The cobalt(II)-iron(III) derivative shows a ferromagnetic order below $3 \mathrm{~K}$.

\section{SYNOPSIS (Text)}

New bidimensional cyanido-bridged heterometallic coordination polymers, $\left[\mathrm{Co}_{3}^{\mathrm{II}} \mathrm{Fe}^{\mathrm{III}}{ }_{2}\right]$ and $\left[\mathrm{Fe}_{3}^{\mathrm{II}} \mathrm{Co}_{2}^{\mathrm{III}}\right]$, have been assembled following the building-block approach. The cobalt(II)-iron(III) derivative shows a ferromagnetic order below $3 \mathrm{~K}$. 